\title{
Socio-Economic Characterisation of Resettled Smallholders in Rural Zimbabwe
}

\author{
Emmanuel Ndhlovu \\ University of South Africa, P.O. Box 392, Pretoria, UNISA 0003 \\ matahemanu@yahoo.co.uk
}

\begin{abstract}
The analyses of the socio-economic consequences of the 2000s land redistribution in Zimbabwe have always been biased towards the analyses of the 'production' and 'redistributive' aspects while other equally important features such as 'social cohesion', 'cooperation', 'protection', and 'accumulation' amongst beneficiaries are neglected. Using the Sangwe farm in Chiredzi as a case study, this article departs from the conventional use of the political economy, sustainable livelihoods, human rights-based and neo-patrimonial approaches. It experiments with the transformative social policy approach positing that this approach includes the features which are ignored in dominant analyses. Using both quantitative and qualitative data in an exploratory research design, the article shows that viewed from this social policy perspective, the 2000s land reform was not a mere resounding success nor was it a complete disaster. The programme actually produced mixed results. There is therefore, the need to deploy eclectic approaches in the analysis of its consequences.
\end{abstract}

Keywords: Chiredzi; livelihoods; Sangwe; smallholders; transformative social policy; Zimbabwe

\section{Introduction}

Most economies in sub-Saharan Africa (SSA) - particularly in the post-colonial era, have largely focused on agricultural activities to develop themselves. This claim can be confirmed by the continued interest in agricultural-based development economics especially amongst development economists in the region (Gumede, 2018; Moyo, 2016). In the early 1960s, agricultural economists such as Johnston and Mellor (1961), Moyana (1975), and Palmer (1977) first introduced the discussion to academic platforms. Today, the hypotheses proposed by these economists and others continue to direct development imperatives as it is increasingly becoming accepted that agriculture dominates the economic practice and activities of the majority of people in the SSA. The majority of households in the region depend on agricultural activities for food production, employment creation, and income generation (Deininger, Hoogeveen, and Kinsey, 2016). Even the Gross Domestic Product (GDP) of countries in the region, except in Botswana and South Africa where it contributed $17 \%$ and $14 \%$ respectively, agriculture has been a major economic practice since the mid-2000s (Kanyenze, 2006). At the waning of Zimbabwe's much talked about land reform in the 2000s, agriculture contributed 65\% to the GDP of Angola; Lesotho (80\%); Mozambique (67\%); Namibia (69\%); and Swaziland (61\%) (Ndhlovu, 2017). In Zimbabwe, agriculture contributes around $67 \%$ into the total GDP of the country (The World Factbook, 2016). As a result of the great potential of agriculture as a livelihood development tool in Africa, most countries have focused on this sector to improve the lives of their people. This explains why agriculture has continued to 
receive increased attention in the post-independence era ahead of the other economic sectors. It is also argued that since Africa is an agrarian community, with most national economies relying directly on it for employment (85\% for Malawi; (75\% for Mozambique; 73\% for Madagascar; 65\% for Zimbabwe; and 65\% for eSwatini) (World Bank 2018), the kind of development that needs to be pursued should be agrarian-based, although linked to prospects of industrialisation and autonomous development (Ndhlovu, 2020).

One important factor which has continued to promote focus on agricultural development than the rest of the economic sectors on the African continent is affordability in terms of capital availability and sectorial expertise. Most governments were resource poor at independence. Therefore, they opted to begin their development agenda on agriculture mainly because the general populace in the region have had indigenous skills in agriculture than in the other economic sectors. While currently, the region seems to be experiencing low levels of agricultural productivity, mainstream market expertise and participation of farmers on the region is known globally to be advancing in crop farming, horticulture, fisheries, and livestock production, albeit, predominantly for subsistence reasons.

Agricultural activities in the region are characterised by intensive subsistence farming and surplus-based informal marketing. One of the sub-regions dominated by subsistence agricultural activities in the region is the Southern Africa Development Community (SADC). The SADC comprises 14 countries most of which had suffered colonial rule by countries such as Britain, German, France, and Portugal. At independence, most of these countries were faced with deeprooted poverty amongst their vulnerable populace. Formally or informally, the poor in these countries increased their reliance on agriculture for survival. This article is focused on Zimbabwe which is one of the countries that have focused on agriculture for the development of its economy and the sustenance of its people. The major research questions of the article are phrased as: What are the socio and economic benefits of resettled smallholder producers on the Sangwe farm? What could be the contribution of the transformative social policy approach in the analysis of the socioeconomic benefits of smallholders on the Sangwe farm?

After the introduction, the article presents a discussion on the transformative social policy as the theoretical framework guiding analysis and the presentation of results. This is followed by an overview characterisation of the study area; the discussion on the Fast Track Land Reform Programme (FTLRP); the research methodology for the study, and presentation of results, respectively. Lastly, the article makes conclusions and recommendations.

\section{Land Redistribution and the Social Policy}

Social policy relates to some public actions which can lead either to the safeguard or to the harm of people who are located in certain areas (Adesina, 2007). For the World Bank (2005), social policy relates to a series of public policies which are designed to inspire social development. This can be land reform or community development projects. Mkandawire (2001, p.1) defines social policy as "collective interventions directly affecting transformations in social welfare, social institutions and social relations... [as well as] access to adequate and secure livelihoods and 
income." Viewing social policy as important for national development, Mkandawire (2001, p.12) argues that it is also "...an instrument for ensuring a sense of citizenship [and] an important instrument for conflict management, which is in turn a prerequisite for sustained economic development..." Hall and Midgley $(2009$, p.6) view the policy as “...encompassing any planned or concerted action that affects people's lives and livelihoods."

Expanding on the notion of transformative social policy, Gumede (2018, p.5) suggests that the policy should include methods for change, "as in transforming social relations and institutions." Mazwi, Muchetu and Chibwana (2017) posit that what is crucial as part of this policy is land reform and other redistributive policies. They further argue that at the heart of the social policy "... is the need to guarantee that every citizen lives a life of dignity regardless of status, ethnicity, age, gender and any other distinctive feature" (p.3). In the context of rural development programmes such as land reform, the social policy does not just involve protection, vulnerability, destitution, and short-term risk analysis, but also "cater[s] for production, protection, reproduction, re-distribution and social cohesion" (Mazwi et al. 2017, p.4). Thus, using this approach, the article demonstrates how land recipients under the FTLRP on the Sangwe farm were impacted on whether for good or for bad.

When it comes to the analysis of the consequences of the FTLRP in Zimbabwe, a growing body of literature has largely been biased towards the analysis of the 'production' and 'redistributive' aspects while other equally vital important features such as 'social cohesion', 'protection' and 'accumulation' amongst beneficiaries are neglected. While 'productivity' and 'redistribution' are the easiest to measure quantitatively in assessing whether land redistribution is an effective social policy tool, it is crucial to rise above 'production' and 'redistribution' features and also examine other needs that exert their pressure in specific territories. A huge body of literature uses human rights-based, political economy, sustainable livelihoods, and the neopatrimonial approaches in the analyses of land reform in Zimbabwe (see Chaumba, 2006; Mazwi and Mudimu, 2019; Moyo, 2011a; Zamchiya, 2011). The excessive deployment of these approaches, however, fails to provide an eclectic debate on our understanding of the consequences of land reform. For example, the human rights-based approach emphasises people's rights that were violated during the FTLRP while it largely neglects their rights that were not violated. The approach also focuses on the promotion of the rights of the minority whites whose farms were acquired by the state and redistributed to the black majorities and neglects the rights of blacks that were fulfilled. Thus, there is no balance in the discussion of these violated rights, thereby, making it difficult for us to gain an overall understanding of the exact socio-economic impact of the programme as a whole. On the other hand, the political economy, and neopatrimonial analyses focus on class-based and chaos analyses that emerged with or that accompanied the FTLRP. This tendency sidelines some crucial land reform aspects such as reproduction, social cohesion and cooperation, and protection which are very important when analysing public policies such as land reform. The livelihoods approach on the other hand, is vague on the role which institutions should play in ensuring that land beneficiaries are empowered through land and agriculture-related activities. 
On the contrary, the transformative social policy approach transcends simply focusing on exposure, protection, and poverty of land beneficiaries, but also focuses on the people's production and reproduction, protection, re-distribution, and social cohesion aspects. In this way, the approach has the potential to close the knowledge gap inherent in the other approaches by indicating the link between land reform and some of the basic elements of the social policy. It could allow us to scrutinise the production curves amongst land receivers at the local level so as assess whether land reform is an efficient social policy tool in attending to the basic needs of the people.

\section{Characterisation of the Study Area}

Zimbabwe is located within Southern Africa between the Zambezi and Limpopo rivers. It is one of the 14 countries constituting the Southern Africa Development Community (SADC). In the year 2019, approximately 14.659.325.0 million people lived in Zimbabwe (The United Nations World Population Review, 2020). The inhabitants of Zimbabwe spread over an area of approximately 96.213.120 square kilometres. The country is divided into five agro-ecological regions according to the amount of rainfall received. Region I receives high rainfall amounts (more than $1000 \mathrm{~mm}$ per annum in areas lying below $1700 \mathrm{~m}$ altitude, and more than $900 \mathrm{~mm}$ per annum at greater altitudes), region II receives moderately high precipitation $(750-1000 \mathrm{~mm})$, region III receives moderate rainfall $(650-800 \mathrm{~mm})$, region IV receives fairly low rainfall amounts $(450-650 \mathrm{~mm})$ while region $\mathrm{V}$ receives lower amounts of rainfall (below $650 \mathrm{~mm}$ in the Zambezi valley and below $600 \mathrm{~mm}$ in the Sabi-Limpopo valleys in which Chiredzi is also situated) (Mugandani, Wuta, Makarau \& Chipindu, 2012, p.362). The majority of the Zimbabwean people live in the rural areas (approximately 9.854.398.0). In the same year, the total number of the rural poor was estimated at 8.307.257.5). In the period leading to the FTLRP, about 67 percent of the total population derived direct livelihoods from land (Central Statistical Office (CSO, 2002).

This study was set in the Chiredzi District which is located in the southeastern part of the country, and close to the Gonarezhou National Park. Chiredzi is in the Masvingo Province. It is dominated by the Shangane people whose livelihoods have always been based on pastoralism and settled livestock (cattle, goats, and sheep) aided with some small scale crop productions. The Shangane people are descendants of Soshangane Manukusa who migrated from South Africa during the Nguni wars in the $19^{\text {th }}$ century and settled in the area bordered by the Save River to the east and the Runde River to the west. After 1934 when their area was designated for the creation of the Gonarezhou National Park, the Shangane people were relocated in the areas such as Malipati, Matibi 2, Ndali, Sengwe, Chilonga, Chileji, and Sangwe. These areas are located around the park. Having virtually lost their land rights, the FTLRP has been the only major attempt by the Shangane to acquired land with land rights.

The major economy drivers in the Chiredzi District are the sugar cane production in the Triangle, Hippo Valley and Mkwasine estates as well as the Chisumbanje estate across the river which manufactures ethanol in the nearby Checheche District. The only other employer, apart from a few isolated mines, estates, and Wildlife Conservancies, is the Government (Chaumba, 2006). The other economic activity in Chiredzi is tourism due to its proximity to the Gonarezhou National 
Park and other Wildlife Conservancies such as Malilangwe Conservation Trust, Chipimbi, and the Save Wildlife Conservancy. In view of this, many households survive on subsistence farming (Chaumba, 2006).

In Chiredzi, the Sangwe is located in the north-east, approximately 50 kilometres from Chiredzi town. It is bordered to the south by Fair Ranch farm, Mkwasine Sugar Estate to the west and north and the Save River which separates the Chiredzi and Checheche districts to the east. The major river that runs close by is the Save River. The Sangwe farm is located in the Sangwe communal area which has five wards that stretch from the Gonarezhou National Park along the Save River to the Save Valley Conservancy in the north. There had been always reports of insufficient land to meet household needs in this communal area since most of the land had been occupied by the Wildlife Conservancies such the Save Conservation Trust, Chipimbi Trust, Fare Ranch, and the Malilangwe Conservancy. Thus, the development of household livelihoods has always been an issue requiring urgent attention on the Sangwe and in the Chiredzi district as a whole. However, high population densities, low amounts of annual rainfall, as well as high temperatures continue to undermine households' efforts to develop their livelihood activities around agricultural activities. According to Ndhlovu (2017), harsh agro-ecological conditions in the district have encouraged the adoption of non-farm activities, conducted both within and outside the district as a way of supplementing household livelihoods.

In this study, the Sangwe farm was selected as the case study as it is the largest of all the farms that were acquired under the FTLRP in the district. It is also the largest political constituency in the whole country. In addition, the farm was selected because it is dominated by the Shangane people who are the only pastoralist group in Zimbabwe. The FTLRP therefore, forced this group to settle and to practice subsistence crop production. This article thus, examines the socioeconomic benefits of these people almost two decades after their resettlement. The transformative social policy approach is used ahead of the dominant human rights-based, political economy, sustainable livelihoods, and the neo-patrimonial approaches.

\section{The Fast Track Land Reform Programme}

Zimbabwe initiated a fast-tracked land redistribution process commonly known as the Fast Track Land Reform Programme between 2000 and 2003. This programme was meant to correct the racially-skewed landownership pattern which had been inherited at independence in 1980 whereby fewer than 6000 white farmers owned $51 \%$ of all the farming land while a total of $72 \%$ of the black majority eked for a living in the Communal Areas (CAs) were they scrambled for $42 \%$ of the land most of which located in dry areas such as the Lowveld where rainfall amounts rarely reach 500mm per annum (Mugandani, Wuta, Makarau, and Chipindu, 2012). Under the FTLRP, by 2010, about 13 million hectares were reassigned to about 240,000 landless black households (Moyo, 2013). The programme was not only redistributive in nature, but also significantly reorganised tenure systems from freehold to state-based tenure, referred to as 'the nationalisation of land' (Mazwi and Mudimu, 2019). It institutionalised a tri-modal agrarian structure made up of the peasants (communal areas, old resettlement and A1 farms), medium to large scale farms (A2 farms), and 
agro-estates (state or private owned), agro conservancy and institutional estates (Moyo, 2011a). The FTLRP was a complete departure from the widely revered market-based 'willing-buyer, willing-seller' arrangement of land reform promoted by the International Monetary Fund and the World Bank.

Although widely celebrated by countries in the Global South, the FTLRP has received intense vilification in the Global North where it is dismissed as an economic disaster which produced food insecurity, unemployment, degraded natural environment, international boycott, lack of agricultural production and declining people's livelihoods (Raftopoulos and Phimister, 2004). Of course the programme had its own challenges. As a result of its chaotic and shortcircuited nature, capital fight was experienced as money lending institutions withheld funding for the new farmers. However, in view of its redistributive nature as summarised in Table 1 below, the FTLRP was important especially for rural dwellers who were concentrated on marginal lands in CAs where their participation in farming remained peripheral.

Table 1: The New Land Structure in Zimbabwe

\begin{tabular}{|c|c|c|c|c|c|c|}
\hline \multirow{2}{*}{ Farm Class } & \multirow[b]{2}{*}{ Land Tenure } & \multicolumn{2}{|c|}{ Farms/Households } & \multicolumn{3}{|c|}{ Areas } \\
\hline & & Numbers & $\%$ of Total & $\begin{array}{l}\text { Hectares } \\
\text { (millions, } \\
\text { ha) }\end{array}$ & $\%$ of Total & $\begin{array}{l}\text { Farm } \\
\text { Size (ha) }\end{array}$ \\
\hline Smallholder & $\begin{array}{l}\text { Communal } \\
\text { Old Resettlement } \\
\text { A1 } \\
\text { Sub-total }\end{array}$ & $\begin{array}{l}1.100 .000 \\
75.000 \\
145.800 \\
1.321 .000\end{array}$ & $\begin{array}{l}81.2 \\
5.5 \\
10.8 \\
97.6\end{array}$ & $\begin{array}{l}16.400 \\
3.667 \\
5.759 \\
25.286\end{array}$ & $\begin{array}{l}49.9 \\
11.2 \\
17.5 \\
78.6\end{array}$ & $\begin{array}{l}15 \\
49 \\
40 \\
20\end{array}$ \\
\hline $\begin{array}{l}\text { Small-to } \\
\text { Medium } \\
\text { size } \\
\text { Commercial }\end{array}$ & $\begin{array}{l}\text { Old SSCF } \\
\text { Small A2 } \\
\text { Sub-total }\end{array}$ & $\begin{array}{l}8.500 \\
22.700 \\
31.200\end{array}$ & $\begin{array}{l}0.6 \\
1.7 \\
2.3\end{array}$ & $\begin{array}{l}1.400 \\
3.000 \\
4.400\end{array}$ & $\begin{array}{l}4.3 \\
9.1 \\
13.4\end{array}$ & $\begin{array}{l}165 \\
133.9 \\
142\end{array}$ \\
\hline $\begin{array}{l}\text { Large-scale } \\
\text { Commercial }\end{array}$ & $\begin{array}{l}\text { Medium-Large } \\
\text { A2 } \\
\text { Black LSCF } \\
\text { White LSCF } \\
\text { Sub-total }\end{array}$ & $\begin{array}{l}217 \\
956 \\
198 \\
1.371\end{array}$ & $\begin{array}{l}0.07 \\
0.03 \\
0.01 \\
0.11\end{array}$ & $\begin{array}{l}0.509 \\
0.531 \\
0.117 \\
1.157\end{array}$ & $\begin{array}{l}1.6 \\
1.6 \\
0.4 \\
3.5\end{array}$ & $\begin{array}{l}2.345 \\
555 \\
593 \\
844\end{array}$ \\
\hline $\begin{array}{l}\text { Corporate } \\
\text { Estates }\end{array}$ & $\begin{array}{l}\text { Corporates } \\
\text { Conservancies } \\
\text { Parastatals } \\
\text { Institutions } \\
\text { Sub-total }\end{array}$ & $\begin{array}{l}20 \\
8 \\
106 \\
113 \\
247 \\
\end{array}$ & $\begin{array}{l}0.001 \\
0.001 \\
0.01 \\
0.01 \\
0.022 \\
\end{array}$ & $\begin{array}{l}0.806 \\
0.247 \\
0.296 \\
0.146 \\
1.495 \\
\end{array}$ & $\begin{array}{l}2.5 \\
0.8 \\
0.9 \\
0.4 \\
4.5\end{array}$ & $\begin{array}{l}40.320 \\
30.875 \\
27.88 \\
1.289 \\
6.051 \\
\end{array}$ \\
\hline Total & & 1.3554 .00 & 100 & 32.878 & 100.0 & 24.3 \\
\hline
\end{tabular}

Source: Moyo (2011c)

Most of the rural dwellers obtained land under the A1 model (small-sized) in which they continue to operate in subsistence arrangements. Subsistence farming has been an integral part of the livelihoods of Zimbabwean people for so many years. It is also shared and widely practiced by the majority of indigenous Africans in many other parts of Sub-Saharan Africa (Meinzen-Dick, Johnson, Ouisumbing and Njuki, 2011; Moyo, 2011a). Thus, despite its challenges, the FTLRP is 
viewed by the rural folk in Zimbabwe as the highest level of the liberation struggle which finally restored their lost lands. It is therefore, crucial to examine what the beneficiaries have so far gained, two decades after being resettled.

\section{Research Methods}

The main objective of the study was to examine the socio-economic benefits accrued by smallholder farmers under the FTLRP in Zimbabwe from a transformative social policy perspective. Additionally, the study sought to determine the perceptions held by households on their resettlement; and also to examine the constraints to production on the farm. To achieve the objectives, the study gathered both quantitative and qualitative data. The unit of analysis was the household. Questionnaires and interviews were used to gather primary data on land use and ownership; asset creation; livestock ownership; income profile; household resilience, and vulnerability context from a sample of 72 households while interviews were used to solicit data from 12 selected key informants. Purposive sampling was used to select all participants. Descriptive and analytical methods of research were used to find a systematic explanation for the benefits of resettlement under the FTLRP. The article also draws from a huge body of literature on land reform in Zimbabwe. Data was analysed according to the selected components of the transformative social policy approach, namely; redistribution, production, income generation, social protection, and social cohesion and cooperation.

\section{Results and Discussion}

The discussion of the results is structured according to the transformative social approach components identified in the literature.

\section{Land Redistribution}

Participants on the Sangwe farm indicated that the FTLRP was highly redistributive; and that it also attempted to grapple with the gender imbalances that characterised this patriarchal community. Out of the 72 land recipient households on the Sangwe, $4 \%$ were youths; $23.6 \%$ were between 40 and 60 years; 54.16\% were between the ages of 61 and 70, while $16.6 \%$ were above the age of 70 . A total of $34.72 \%$ were women who also acquired land under the FTLRP on the farm. At the district level, it was found that among the land beneficiaries, about $29 \%$ of them were women (Chaumba, 2006). While men still dominated, it is important to note that this is a good starting point for the empowerment of women since the Shangane people, who make the majority in the district, are patriarchal, and property among these people, including land, is always owned and controlled by men. For instance, on the Fair Range farm, Chaumba (2006) found that out of 70 participants, women accounted for only $8 \%$ of the beneficiaries while men accounted for $92 \%$. However, the current study found that where women had acquired land, access to productive resources was a key challenge (Informant 7). It also found that where women owned land out rightly, the land tended to be located in more marginal areas such as hills, streams or in the periphery where crops were easily grazed by wildlife. This has constrained zeal of many women 
to participate in agricultural activities (Informant 9). Nevertheless, participants indicated that they were pleased by the outcomes of the FTLRP on the farm. Even female participants indicated that the composition of land ownership on the farm represented a change since no woman owned land prior to the programme.

\section{Household Agricultural Production}

The transformative effect of land reform processes in areas resettled under the FTLRP also needs to be juxtaposed against the beneficiaries' perceived quality of life prior to and after resettlement. On the Sangwe farm, a number of participants reported to be doing well. About $56 \%$ reported that even though the area was ecologically dry, they still managed to grow drought-resistant crops that enabled them to have enough grains for food without relying on the ailing state. A total of 50\% grew drought-resistant crops such as sorghum while $27 \%$ grew millet for food and for sale. Households recommended sorghum for its ability to resist drought and for its demand by the Chibuku breweries which has a branch company located in the Chiredzi town. Some households indicated that sorghum was the main crop best suited to the climatic conditions on the farm. Households also grew millet, groundnuts, cowpeas, beans, pumpkins, and other types of crops.

The production of a variety of crops by households should be applauded since it ensures the achievement of a balanced diet. In a non-farming context, it may be difficult, or even very costly to have a balanced diet (carbohydrates; from maize and sorghum; fats and proteins; from cowpeas; groundnuts; vitamins; from vegetables such as pumpkins and sweet potatoes). This is crucial considering the country's effort towards food sovereignty. Household food security is a major component of human existence. It entails a condition in which all members of the household have adequate food to eat (Ndhlovu, 2017). The availability of adequate food is enshrined in the United Nations Declaration of Human Rights. In this view, from the transformative perspective, the FTLRP yielded positive results on the Sangwe farm. This evidence, however, has to contend with the increased number of donor activities which provide maize grains and cooking oil to households on the farm.

The presence of large herds of livestock and flocks due to abundant pastures was celebrated by participants as one of the major advantages of their resettlement. There were, however, a number of income generation activities listed by participants as shown later in the article. Such a change of income generation sources towards non-agricultural activities is a matter of concern considering that the FTLRP was meant to boost national development and also promote agricultural-dependent livelihoods.

The study also found that the majority of beneficiaries $(54.16 \%)$ were between the ages of 61 and 70. This may support the view that the beneficiaries of the FTLRP were war veterans (Chaumba, 2006). This situation may not speak well to the country's commitment to realise inclusive development by focusing on the agricultural sector. The agricultural sector is a labourintensive exercise. It is a sector that requires the intensive contribution of young able-bodied youths as the human capital. The demographic evidence revealed by the study shows that while the land redistribution was largely welfarist and focusing on those who participated or those who 
were displaced by the war, it might as well have failed to factor in the importance of the human capital in this important sector. This has insulted households' efforts to put their labour to productive farming, and has thus, compromised the project's ability to transform the lives of smallholders. In view of these results, it can be asserted that when viewed from the transformative social policy perspective, the programme failed to address the age imbalances inherent in land access and utilisation on the farm.

While most participants reported the adequacy of food availability through their ability to diversify crop production, there were some participants who experienced food shortages. It was reported that while the elderly consumed various dishes of sorghum and millet, children were particularly reluctant to consume these meals due to their colour and taste (Informant 4). Households then still needed to purchase maize grains and other food stuffs to cater for the young. Table 2 shows that some households had to sell certain properties in order to meet other basic requirements on the farm including food. While households did not sell their land, farm equipment and livestock were mostly sold. A total of $51.3 \%$ households had sold an average of three farm equipment since the beginning of 2016 to meet food, school fees, and clothes requirements as well as to buy inputs such as fertilizers, chemicals and seeds. Farm equipment had also been sold to meet circumcision, lobola and other needs by other households. Non-farm equipment such as radios, televisions, tables and chairs, and sewing machines had also been sold to meet the same basic requirements. The sale of assets to access basic needs is a clear indication of stunted livelihoods in an area where people are expected to be depending on their lands for survival. These results could be at loggerheads with government statements that seem to indicate that the FTLRP produced uniform positive results across the country (Deininger, Hoogeveen, and Kinsey, 2016).

However, one key informant explained that in actual fact, farmers invested their savings in the purchase of livestock, flocks, and productive farm equipment, and so forth, with the aim of selling these when a need arose, and therefore, the sale of livestock should not be viewed as an indication of failure by households to survive on farming activities (Informant 9). This form of saving farm returns comes as the people of Zimbabwe have lost trust with the banking sector due to the disorganised and 'immediate effect' policy changes that continue to see bankers losing the value of the deposits in the country. This is also an attempt by households to shield themselves from the hyperinflation which continues to wreck the country's economy, markedly since the 2000s when the FTLRP was initiated.

Table 2: Items sold to meet respondent households' needs $(n=72)$

\begin{tabular}{|l|l|l|l|}
\hline Item & $\begin{array}{l}\text { Number of } \\
\text { households }\end{array}$ & $\begin{array}{l}\text { Quantity Eve\# of } \\
\text { items sold }\end{array}$ & Reasons \\
\hline Land & - & - & - \\
\hline Livestock & 69 & 4 & $\begin{array}{l}\text { food, school fees, lobola, functions, } \\
\text { to buy inputs }\end{array}$ \\
\hline $\begin{array}{l}\text { Farming } \\
\text { equipment }\end{array}$ & 37 & 3 & $\begin{array}{l}\text { Food, school fees, clothes, lobola, } \\
\text { functions }\end{array}$ \\
\hline
\end{tabular}




\begin{tabular}{|l|l|l|l|}
\hline $\begin{array}{l}\text { Non-farming } \\
\text { equipment }\end{array}$ & 72 & 3 & $\begin{array}{l}\text { food, school fees, clothes, to buy } \\
\text { inputs, pay for cultivation }\end{array}$ \\
\hline
\end{tabular}

On the overall, production was steady on the Sangwe farm. Although operating under adverse conditions (political, economic, and agro-ecological), households still managed to produce certain amounts of crops to enable them to survive. The presence of donor actors who also assisted with basic food parcels on the farm continues to shield them from the worst scenarios, especially due to the socio-economic and political stand-offs been the two major political parties in the country - the Zimbabwe African National Union-Patriotic Front (ZANU-PF) and the Movement for Democratic Change (MDC). In this view, it can be asserted that although the 'production' component of the transformative social policy has not yet been fully realised, the households would have been worse outside the FTLRP.

\section{Income Generation}

Economic data was measured by recording the numbers of livestock, flocks, and poultry (Table 3); roof type of houses (Table 4), and farm equipment owned by household (Table 5). The aim was to measure the livestock and asset creation of households.

Table 3 shows that $90.2 \%$ of the households owned cattle. Considering that livestock is a symbol of wealth for the Shangane people who dominate the Sangwe farm, one may assert that the households are doing well on the farm. Households also had donkeys (45.8\%) which are an important source of farm transport and draught power (Informant 7). They also owned flocks (goats $(97.2 \%)$ and sheep (23.6\%), and poultry (pigs, rabbits, ducks, and chickens) (100\%). The possession of livestock and flocks enabled households to attain and sustain their livelihoods in an agro-ecological dry area such as Chiredzi. Goats were applauded by participants for their disease and drought resistance and their ability to sell fast in times of emergences. While some households reared pigs and ducks, others avoided them due to religious affiliations.

Personal observations revealed that households had developed skills on how to rear animals, train animals to do farm work such as pulling the plough, pulling scotch carts, and also dragging thorny tree branches and tree logs that would be used for kraal constructions. The thorny branches were meant to deter wild animals from attacking livestock. Households also hired out their scotch carts transport to those who did not have such assets. This augmented their incomes (Informant 10).

Table 3: Ownership of livestock $(n=72)$

\begin{tabular}{|l|l|l|}
\hline Type & Frequency & Percentage \\
\hline Cattle & 65 & 90.2 \\
\hline Donkeys & 33 & 45.8 \\
\hline Sheep & 17 & 23.6 \\
\hline Goats & 70 & 97.2 \\
\hline Pigs & 7 & 9.7 \\
\hline
\end{tabular}




\begin{tabular}{|l|l|l|}
\hline Poultry & 72 & 100 \\
\hline
\end{tabular}

One key informant mentioned the importance of livestock ownership in the following words:

Without cattle or donkeys, it is very hard to survive on this farm. You need livestock for everything from draught power to transport. This is a neglected and very far away area and transport is needed to go to the clinic or to the hospital. Without cattle, you are the poorest of the poor on the Sangwe (Informant 9).

In terms of housing, however, Table 4 shows that even after 18 years of agricultural operations and resettlement on the farm, households still lacked basic and proper shelter. A total of $69.4 \%$ still used typical Shangane huts of pole and dagga such as those seen in their previous communal areas. About 23.6\% owned asbestos-roofed houses while only 1.3\% owned a two-roomed tiled house. Animal shelter was also made of poles, dagga, logs and branches. Most of the housing structures on the farm therefore, did not offer adequate protection for households and their livestock. The common pole, dagga, and branch structures exposed livestock to wild animals such as hyenas and lions which are common in the area since it is close to Wildlife Conservancies and also to the Gonarezhou National Park. The vulnerability of livestock and exposure to wild animals affected households that invested their savings in the form of livestock. This in turn negatively impacted their income generation.

Table 4: House types in the case study area $(n=72)$

\begin{tabular}{|l|l|l|}
\hline Roof type & Frequency & Percentage \\
\hline Tiles & 1 & 1.3 \\
\hline Asbestos & 3 & 4.1 \\
\hline Zinc & 17 & 23.6 \\
\hline Advanced thatch & 1 & 1.3 \\
\hline Ordinary thatch & 50 & 69.4 \\
\hline
\end{tabular}

Households also owned farming equipment as summarised in Table 5 which shows that $90.2 \%$ of households had ploughs for cultivating the fields. About $37.5 \%$ had scotch-carts for onfarm and off-farm transportation; 63.8\% had wheelbarrows, while other households also owned shovels, harrows, and equipment in varying quantities. In-depth investigations, however, revealed that in actual fact, some of the equipment which households had on the farm was bought before the FTLRP. Some equipment also belonged to relatives who are in the communal areas (Informant 4) and is therefore not the result of agricultural activities on the farm. However, what is essential to acknowledge is that this farming equipment, although not personally-owned by A1 households, is on the farm where it is being put to productive use for income and crop production. Other households, however, managed to buy their own farming equipment by the proceeds of the farm and also through the assistance of their social networks, including ZANU-PF farmer programmes. This was revealed by one informant who mentioned that some households had received equipment 
such as scotch carts, ploughs, and hoes from this political party (Informant 3). This informant stressed that providing equipment to farmers indicated the party's continued commitment to make the land reform project a success. In this view, the provision of improved, particularly modern technologies to these households could assist them, not only to develop their livelihoods, but also to make a meaningful contribution to the rural economy, and consequently, to the broader economy.

Table 5: Assets owned by the respondent households $(n=72)$

\begin{tabular}{|l|l|l|}
\hline Type & Frequency & Percentage \\
\hline Ox Plough & 65 & 90.2 \\
\hline Ox ridger & 7 & 9.7 \\
\hline Ox harrow & 9 & 12.5 \\
\hline Ox cultivator & 4 & 5.5 \\
\hline Harrow & 3 & 4.16 \\
\hline Scotch cart & 27 & 37.5 \\
\hline Wheelbarrow & 46 & 63.8 \\
\hline Hoe/shovel & 72 & 100 \\
\hline Tractor & 3 & 4.16 \\
\hline Lorry & 2 & 2.7 \\
\hline
\end{tabular}

Participants also reported that they were making some incomes from both farm and offfarm activities. The sources of income for households included entrepreneurship, formal employment, and remittances from family members. Education was also listed by the households as an income-generating activity as it increases a person's chances for security formal employment (Informant 12). A total of $19.4 \%$ had employment as their major source of income. The use of probing questions revealed that most of the heads of these households were formally employed either in the Hippo valley, Triangle or Mkwasine sugar estates. Some were also employed in the surrounding Wildlife Conservancies such as Malilangwe and the Save Trust while some were employed outside the country. About 29.1\% mentioned that they depended on remittances from family members. Most households had at least one family member who worked in countries, such as the United Kingdom, Mozambique, Botswana, South Africa, and Australia. Only 16.6\% depended on selling cash crops while $4.1 \%$ depended on the sale of livestock. A total of $15.2 \%$ survived on hawking. These households sold vegetables, milk, mopane worms, honey, and firewood collected from their plots. Another 9.7\% mentioned that it depended on selling game meat and fish for survival. When asked why this was the case, one informant revealed that:

We have no option. The people have no option. This is a dry area and farming is not good, it is not good at all. Maybe if you grow sorghum, yes, sorghum, then you have better chances to get a harvest. Beside that forget. You will suffer. The children will suffer. So, we make a plan. A man must make a plan. We get into the bush and get meat so that we can sell and feed the children, you see (Informant 6).

The absence of adequate employment opportunities by household members is a major 
constraint on households that still need to purchase equipment for agricultural production. In view of these results, the 'income generation' aspect of the social policy approach on the Sangwe farm is still to be experienced as most households still basically work 'from hand to mouth' with no savings to plough back into their farming activities.

\section{Social Protection}

Social protection is one of the key features of the transformative social policy. Adesina (2015:4) posits that the "transformative role of social policy stretches from the economy to social relations and social institutions... [and] involves a wide range of instruments to raise human well-being, transform social institutions, social relations and the economy..." In other words, this approach transcends the provision of social assistance programmes to include social security aspects such as health, education, and land reforms. Participants in this study agreed that the FTLRP increased their social protection as they now own the means of production - the land. This is supported by Ndhlovu (2020) who posit that in Africa, land is wealth, and that land and agrarian activities play a vital role in the livelihood development of many former settler colonies such as Algeria, Kenya, South Africa, Namibia, Tunisia and Zimbabwe; and even among those that did not experience settler colonialism such as Botswana, Ghana, Malawi, and many others. This was confirmed by various scholars such as Chibwana (2016) and Mkodzongi (2013) who found the transformative effect of the FTLRP in different case studies in terms of improving land ownership.

Infrastructure such as transport networks, health and educational facilities, markets, and water supplies are vital in transforming the lives of resettled families on the Sangwe farm. It is however, regrettable that almost two decades since the implementation of the FTLRP, there were still no standard transport networks on the farm. As a result, there were also no markets. To access markets, households travelled to the Fair Range farm which is almost 20 kilometres away due to lack of markets on the farm. The same distance was travelled to get transport to go to different areas. While scotch-carts, bicycles, and motorbikes were the dominant source of transport due to the inaccessibility of the area and also due to fuel shortages in the country, during rainy seasons, these transport types cannot be used due to the nature of the basaltic soils in the area which are sticky when wet. Thus, people have to travel on foot to the main Ngundu-Mutare Road to get transport. The basaltic soils in the area easily become very muddy due to fine texture and shallowness. A total of $51 \%$ of the participants identified geographic and climatic conditions as a major challenge to their livelihood activities on the farm.

In terms of educational facilities, the only schools that were nearby were Hlanganani, Nyahanga, Jekero, and Machoka which are more than 30 kilometres from the farm (Interview 4). Most children still lived in previous communal areas in order to be in the proximity of schools. This impacted on the labour available on the farm. There were also no health and sanitary facilities on the farm. Families travelled to Gudo, Rupangwana, and Masekesa for clinical services while they travelled to Chiredzi town (about 50km away) for hospital services. Other members crossed the Save River to access health facilities at the Vheneka clinic and the Saint Peters hospital in the Checheche District. The prevalent diseases reported by households on the farm included malaria 
(52\%), cholera (36\%), diarrhea (29\%), and HIV (32\%). Malnutrition was reported as a challenge by $27 \%$ of the households. This issue was also captured by the SAFIRE (2004) which posits that lack of access to markets due to poor roads and distance in the district as a whole remained one of the health challenges which constrained production on smallholder farms. From a transformative social policy perspective, this reality renders families extremely vulnerable to diseases, hunger, and increased poverty.

There were also water supply shortages on the farm. While households reported that they used wells and boreholes for water, only $69 \%$ of them owned wells while another $31 \%$ used wells which belonged to neighbours. All the boreholes that had been drilled by the municipality were reported to be broken by the time of the study (Informant 11). These realities are not in consistent with the country's discourse to ensure rural development. Participants also reported that the Department of Veterinary Services, which is responsible for vaccinating and monitoring animal disease outbreaks seemed to be biased towards A2 (medium-sized) farmers in the district while neglecting A1 farmers. Due to the Sangwe farm's proximity to wildlife conservancies, a total of $4 \%$ complained of wild animals which killed their livestock while $17 \%$ complained of grazed crops during the night. Participants however, mentioned that although they did not have health facilities, there were some health agents on the farm who were trained by the health department to distribute tablets and also monitor hygiene on the farm. Overall, the shortages of social services on the farm require the government, both local and national, to work together, and physically deliver infrastructure as part of the continued effort to ensure that the FTLRP releases transformative outcomes.

\section{Social Cohesion and Cooperation}

When analysing the impact of the FTLEP, it is important to go beyond production and protection aspects, and also take on board the possibility for social cohesion and cooperation which, for smallholders, may be more vital than could be realised. Social cohesion is one of the basic components of the transformative social policy approach. Although it is multi-faceted, it can be expressed in four main categorises, namely; social, task relations, perceived utility, as well as emotion. It is defined by Burns, Hull, Lefko-Everett, and Njozela (2018, p.10) as “...the extent to which people are co-operative, within and across group boundaries, without coercion or purely self-interested motivation." It entails "understanding the social infrastructure, institutions, customs and material and non-material relations that either constrain or enable the individual in whatever pursuit they are engaged" (Murisa, 2007, p.2). At the highest level of generality, it denotes the aptitude or the potential of smallholders to build a shared identity and a sense of belonging. The promotion of social cohesion on the Sangwe is one of the most difficult, yet most critical challenges. The FTLRP, unlike previous resettlements in Shangane territories, managed to bring together people from different backgrounds, tribes, cultures, and beliefs, and yet, as noted by one key informant, these people had to join forces in defying the basic challenges relating to occupying targeted land; intimidating white farmers not to reoccupy the land; lobbying for recognition as new 
owners; natural resources management; and lobbying for agricultural inputs acquisition, etc. (Informant 9).

Social cohesion and cooperation in the form of networks (political and communal), cultural norms (formation of cooperatives), and other social attributes has been essential in the sharing of knowledge (Informant 7), exchanging experiences, and cooperation among farmers on the Sangwe (Informant 11). The networks and cooperatives of farmers are very important as they increase the chances for increased productivity. Productivity is a vital component of transformative social policy approach as it also increases the social protection of farmers. Participants reported that members who had received agricultural training assisted others with procedural support on the farm (Informant 5). Households also engaged in cooperatives during ploughing, weeding, and harvesting sessions to make the work easier. They also shared farm equipment and other farm services. These networks are vital as they increase productivity. Networks are also useful in increasing the social protection of households. It was also revealed that farmers also established transport cooperatives to transport products, mostly cotton bales to the market which was located on the Fair Range farm (Informant 8).

However, at a district level, informants reported that social cohesion in the Chiredzi District as a whole could remain a challenge due to the historical animosity among the tribes, namely; the Shangane, Ndau, and Karanga that were mixed in resettled farms. This has resulted in continuous contests for control by each tribe. In the FTLRP, these issues were not considered in land accessibility. This was one of the issues likely to undermine the transformative potential of the FTLP on the farm.

\section{Conclusion and Recommendations}

While political economy, human rights-based, sustainable livelihoods, and neo-patrimonial approaches have resulted in a growing body of informative literature regarding the consequences of land reform in Zimbabwe, this article demonstrates the importance of experimenting with the transformative social policy perspective. The article argues that the FTLRP produced mixed results, and therefore, should not be merely vilified as the source of Zimbabwe nose-dive into economic chaos, or simply celebrated as a resounding success. It has been hit by teething problems within the context of economic breakdown, but it was necessary and has some very positive outcomes. The article also notes that although the FTLRP has received immense research attention, research on the transformative potential of the programme particularly for smallholders in agro-ecological dry areas such as Chiredzi has been largely ignored. This is despite the fact that the majority of resource-poor rural communities in this district depend mostly on agricultural activities for survival. The article critically evaluates the impact of the FTLRP on the Sangwe farm from a transformative social policy perspective. The results showed that land ownership through the FTLRP is critical for household nutrition, income generation, social cohesion, and livelihoods development. A substantial number of the farmers obtained their incomes from the sale of crops while others from the sale of livestock, flocks, and poultry. Farmers sold their livestock to raise cash to access other basic needs. The proceeds from land were also sold to raise cash to assist these 
households to raise school and circumcision fees for their children and also pay lobola.

However, the full impact and efficiency of the FTLRP in Chiredzi has been experiencing a variety of complexities. Geographic, political, economic, and climatic conditions, unemployment, and unavailability of inputs, lack of land security, unsustainable market prices, inadequate institutional and organisational support, and tillage and lack of draught power are some of the challenges. In view of the results, the article concludes that viewed from a transformative social policy perspective, the FTLRP cannot merely be viewed as a resounding success simply because it completed what is now widely considered to be Zimbabwe's incomplete decolonisation as it finally ensured the long-awaited redistributive land justice. On the other hand, it cannot be simply labelled as a complete disaster which resulted in food insecurity, unemployment, degraded natural environment, international boycott, lack of agricultural production, and declining people's livelihoods (Zamchiya, 2011). The programme actually produced mixed results. There is therefore, the need to deploy in-depth case study approaches in the analysis of its consequences.

The study recommends local and national governments, as well as the Agriculture Research and Extension services (AREX) board to conduct researches in which the current land reform policy and agro-ecological adaptation can be considered in the collective efforts of improving the transformative agenda of the FTLRP across the country. In addition, training on both subsistence and commercial farming should be provided at all levels of community development structures particularly for government officials who are directly involved in the design, planning and implementation of rural development projects. This will speed up the ability of smallholders to channel their labour to diversified production. Such training should also involve community development officers.

\section{References}

Adesina, J. O. (2007). Social Policy in sub-Saharan African Context in Search of Inclusive Development. New York: Palgrave Macmillan.

Adesina, J.O. (2015). Return to a Wider Vision of Social Policy: Rereading Theory and History. South African Review of Sociology. 46:3, 99-119.

Burns, J., Hull, G., Lefko-Everett K \& Njozela, L. (2018). Defining social cohesion. Cape Town: SALDRU, UCT. (SALDRU Working Paper Number 216).

Central Statistical Office (CSO). (2002). Preliminary Results Summary: Census 2002. Central Statistical Office: Harare.

Chaumba, J, A. (2006). Opportunities for and Constraints on crop Production within Zimbabwe's Fast track Resettlement Programme: A Case Study of Fair Range Estate,

Chiredzi District, South Eastern Zimbabwe. University of Western Cape: Programme for Land and Agrarian Studies (Unpublished Masters of Philosophy thesis).

Chibwana, M. W. T. (2016). "Social Policy Outcomes of Zimbabwe's Fast Track Land Reform Program (FTLRP): A Case Study of Kwekwe District." Doctoral Thesis, Pretoria: University of South Africa (UNISA).

Deininger, K, Hoogeveen, H \& Kinsey, B. (2016). Benefits and costs of land reform in Zimbabwe with implications for Southern Africa. World Development 26. Government of Zimbabwe. (2001). Zimbabwe's Land Reform Programme, Harare. 
Johnston, J \& Mellor, W. (1961). The role of agriculture in Economic Development.Econ. Rev. 51, September: 566-593.

Gumede, V. (2018). Social policyfor inclusive development in Africa: Revisiting Development Discourse. Third World Quarterly, 39, 1, p1-17, p.5.

Hall, C, M \& Frost, W. (2009). 'The Making of the National Parks Concept'. In Frost, W \& Hall, C, M. (eds). Tourism and National Parks, International Perspectives on Development, Histories and Change. New York: Routledge.

Kanyenze, G. (2006). The Search for Sustainable Human Development in Southern Africa. Harare: ANSA.

Mazwi, F and Mudimu, G, T. (2019). Why Are Zimbabwe's Land Reforms Being Reversed? Economic and Political Weekly, 54(35).

Meinzen-Dick, R, Johnson, N, Ouisumbing, A \& Njuki, J, J. (2011). Gender, Assets and Agricultural Development Programs: A Conceptual Framework. CAPR Working Paper No.99. Washington D.C.: International Food Policy Research Institute. http://www.capri.cgiar.org/pdf/capriwp99.pdf (Accessed on 16/06/2016).

Mkandawire, T. (2001). Social Policy and Development Programme Paper Number 7, June 2001. United Nations Research Institute for Social Development, Geneva, Switzerland.

Moyana, HV. (1975). The Political Economy of land in Zimbabwe. Gweru, Mambo Press.

Moyo, P. (2010). Land Reform in Zimbabwe and Urban Livelihoods Transformation, Working Paper 15, Department of Sociology and Industrial Sociology, University of Fort Hare, South Africa.

- (2011a). Three decades of land reform in Zimbabwe. Journal of Peasant Studies, 38(3):493571.

- (2011b). Land concentration and accumulation after redistributive reform in post-settler Zimbabwe', Review of African Political Economy 38(128): 257-276.

- (211c). Changing agrarian relations after the redistributive land reform in Zimbabwe. Journal of Peasant Studies, 38(5): 907-934

- (2013). "Land Reform and Redistribution in Zimbabwe since 1980," Land and Agrarian Reform in Zimbabwe: Beyond White Settler Capitalism, Dakar, CODESRIA.

- (2018). Third World Legacies: Debating the African Land Question with Archie Mafeje. Agrarian South: Journal of Political Economy 7(2): 1-23.

Mugandani, M, W, Makarau, A \& Chipindu, B. (2012). Re-classification of agro-ecological regions of Zimbabwe in conformity with climate variability and change. African Crop Science Journal, 20(2): 361 - 36.

Murisa, T. (2007). Social Organisation and Agency in the Newly Resettled Areas of Zimbabwe: The Case of Zvimba District. Monograph, Harare: AIAS Monograph Series.

Ndhlovu, E. (2017). An analysis of household livelihoods under the fast track land reform programme in Chiredzi, Zimbabwe. University of South Africa: Pretoria (MA Thesis).

Ndhlovu, E. (2020). Decolonisation of Development: Samir Amin and the Struggle for an Alternative Development Approach in Africa. The Saharan Journal, 1(1): 87-111.

Nthakheni, N, D. (2006). A livestock production systems study amongst resource-poor livestock owners in the Vambe district of Limpopo Province. University of the Free State: Bloemfontein. Unpublished $\mathrm{PhD}$ thesis.

Palmer, R. (1977). Land and Racial Domination in Rhodesia. London: Heinemann.

Raftopoulos, B and Phimister, I. (2004). "Zimbabwe Now: The Political Economy of Crisis and Coercion," Historical Materialism, 12(4): 355-382. 
SAFIRE. (2004). Land-Use and Tenure on Contested Land: Chitsa Community in Gonarezhou National Park, SE Zimbabwe, IUCN Regional Office for Southern Africa, Harare.

The World Factbook. (2016). GDP-Composition by sector of origin. www.cia.gov/library/publication/the-world-factbook/fields/2012.html\#84 (Accessed 24/07/2017).

World Bank. (2005). Concept Note: Rethinking Social Policy. World Bank Conference in Arusha, Tanzania, December 12-15, 2005. Available at: http://worldbank.org/website/ external/topics [Accessed: 22/01/2019].

Zamchiya, P. (2011). A synopsis of land and agrarian change in Chipinge District, Zimbabwe. Journal of Peasant Studies, 38(5): 1093-1122.

The United Nations World Population Review. (2020). World population prospects 2019. Available at http://population.un.org/wpp/ (Accessed 108/01/2020). 